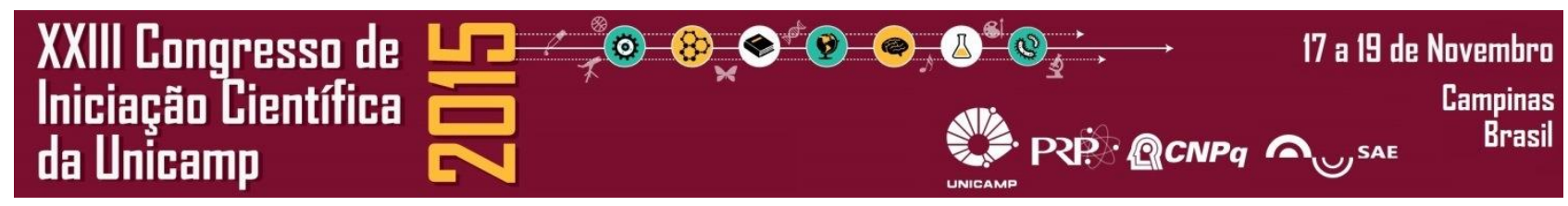

\title{
Videoartistas mulheres e as imagens em diferenciação
}

\section{Resumo}

Fernanda N. Silva (IC), Antonio C R Amorim (PQ)

O objetivo principal desta Iniciação Científica é pensar a obra de videoartistas mulheres a partir da produção filosófica de Gilles Deleuze.

Palavras Chave: videoartistas mulheres, imagens em diferenciação, Gilles Deleuze.

\section{Introdução}

A obra de Gilles Deleuze nos fornece a possibilidade de interpretar os signos da arte como redescoberta do artista e de seu próprio tempo, a qual é consequência de seu processo de aprendizado enquanto inventor do mundo. Tal reflexão nos permite apreciar a obra de videoartistas mulheres enquanto criadoras de imagens da diferença e, por assim dizer, de fraturas em um cenário anestesiado por anacronismos.

\section{Resultados e Discussão}

Tendo em vista que, segundo Deleuze, o artista em seu processo de apreensão caminha de encontro a si mesmo enquanto participante de um mundo múltiplo, e, portanto, não enquanto subjetividade subjugada a uma lógica da identidade, buscou-se aprofundar tal relação com as imagens em diferenciação produzidas por algumas artistas mulheres selecionadas. Para cumprir com esse objetivo, me detive na análise de obras presentes no acervo da videoteca do IA - UNICAMP e também da coleção de DVD's Lowave, a qual reúne um conjunto de obras de cinema experimental e videoarte de artistas, principalmente pertencentes ao BRIC.
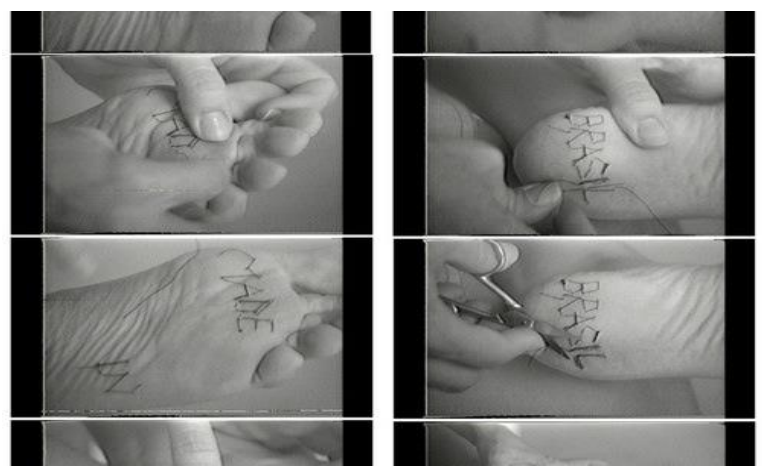

Figura 1. Marca registrada, Leticia Parente.

\section{Conclusões}

As imagens presentes na obra destas mulheres chocam-se umas com as outras em direção contrária ao que é dado no mundo enquanto modelo representacional, indo, portanto, de encontro ao caminho deste artista deleuziano o qual em seu processo de apreensão de signos recompõe o mundo e insiste na criação do novo mesmo em um cenário onde o dogmatismo e a repetição insistem em se perpetuar.

\section{Agradecimentos}

CNPq - Conselho Nacional de Desenvolvimento Científico e Tecnológico

Deleuze, G. Diferença e repetição. São Paulo: Graal, 2009.

Deleuze, G. A imagem do pensamento. In: repetição. São Paulo: Graal, 2009. : Diferença e

eleuze,

DG; Guattari, F. O que é a filosofia? Rio de Janeiro: editora 34, 1992. 